\title{
RELATIONSHIP OF CUSTOMER SERVICE SATISFACTION WITH FINANCIAL INVESTOR'S MARITAL STATUS AND FAMILY TYPE AT GENERAL INSURANCE CORPORATION OF INDIA
}

\author{
A. MUTHUKRISHNAN ${ }^{1}$, B. NATARAJAN ${ }^{2} \&$ K. GOMATHI SANKAR ${ }^{3}$ \\ ${ }^{1,3}$ Assistant Professor, Department of Business Administration, Annamalai University, Chidambaram, Tamil Nadu, India \\ ${ }^{2}$ Professor, Department of Business Administration, Annamalai University, Chidambaram, Tamil Nadu, India
}

\begin{abstract}
In today's global competition, establishment of excellent customer satisfaction is paramount to the success of any business. This study was aimed to establish the difference among the marital status and type of family of GIC of India's customers with their customer service satisfaction. A sample of 550 GIC customers were undergone a survey using customer service satisfaction scale, developed and tested by the researcher in his previous research. With the help of SPSS statistical tool, the collected data was analyzed. The overall customer service satisfaction differs with the customer's family type and Marital status.

KEYWORDS: Service Satisfaction, Family Type, Marital Status, GIC \& Health Insurance
\end{abstract}

Received: Jun 10 2017; Accepted: Jun 25 2017; Published: Jul 13 2017; Paper Id.: IJSMMRDAUG20173

\section{INTRODUCTION}

The primary function of insurance, be it life, non life or reinsurance, is providing protection by assessing the risk and sharing the same with many, by the process of risk sharing and thus, minimizing individual risk and its impact. These basic functions are followed by subsidiary responsibilities like efforts for preventing losses and aiding the economic development through the investment of funds. Insurance pays a significant role in shaping the economy of a nation. The contribution of the insurance sector to the growth of the economy is gauged by the rate of penetration. The rate of penetration means the quantum of premium mobilized by the insurance sector vis-à-vis the growth of the Gross Domestic Product (GDP). The ratio indicates the growth of the insurance market.

In India, insurance is a federal subject and is governed by the Insurance Act 1938 and the Insurance Regulatory and Development Authority Act, 1999. In India, the Insurance business is divided into four classes namely; a. Life insurance, b. Fire insurance, c. Marine insurance and d. Miscellaneous insurance. Life insurers transact life insurance business and general insurance transact the rest. Health insurance falls under the miscellaneous insurance business, but there is no clear demarcation as the same is also offered by the life insurance companies.

General insurance as a whole, developed with the industrial revolution in the West and with the consequent growth of seafaring trade and commerce in the seventh century. In India too, evidence of insurance in some form can be traced as early as from the Aryan period. The British and some of the other foreign insurance companies through their agencies transacted insurance business in India. The first general insurance company in India was the Triton Insurance company Ltd., established in Calcutta in 1850 AD, with the British holding major 
share. The first general insurance company by Indian promoters was the Indian Mercantile Insurance company Ltd. started in Bombay in 1906-07.

As soon as GIC was formed, GOI transferred all the shares it held of the general insurance companies to GIC. Simultaneously, the nationalized undertakings were transferred to Indian insurance companies. After a process of mergers among Indian insurance companies, four companies were left as fully owned subsidiary companies of GIC

- National Insurance Company Limited.

- The New India Assurance Company Limited.

- The Oriental Insurance Company Limited.

- United India Insurance Company Limited.

\section{TYPES OF GIC}

- In Fire Insurance: The construction of building, the nature of its use i.e. whether it is of concrete or Kucha, having thatched roofing, and whether it is being used for residential purposes or as a go down, whether firefighting equipment is available or not.

- In Motor Insurance: The type of vehicle, the purpose of its use, its age (Model), Cubic capacity and the fact that the driver has a consistently bad driving record.

- In Marine Insurance: Type of packing, mode of carriage, name of carrier, nature of goods, the route.

- In Personal Accident Insurance: Age, height, weight, occupation, previous medical history, if it is likely to increase the choice of an accident, and bad habits such as drinking etc.

- Burglary Insurance: Nature of stock, value of stock, type of security precautions taken.

\section{Health Insurance in India}

Before looking into the history of health insurance in India, it is important to know its definition. Health insurance is a form of insurance, whose payment is contingent on the insured, incurring additional expenses or losing income because of incapacity or loss of good health. A Health Insurance Policy is a contract between an insurer and an individual or a group in which, the insurer agrees to provide specified health insurance cover at a premium. Depending on a policy, the premium may be payable either as a lump sum amount or in installments. Health Insurance, generally provides direct payment or reimbursement of expenses incurred during an illness. The nature of protection would depend on the kind of policy purchased and the cost and range of protection under that policy. Health insurance could be either a personal scheme or a group scheme sponsored by an employer. Unlike life insurance, where there are only two parties i.e. the insured and the insurer, in the case of health insurance, there are three parties namely, the insured, the insurer and the provider (network hospital). There is also TPA, which acts as an extended arm of the insurance company and helps in claim processing, managing the hospital networks and at times helping in enrollment of customers.

\section{REVIEW OF LITERATURE}

\section{Insurance}

Mishra, K.C. and Simita Mishra (2000) in their article on "Insurance Industry: Recipe for a Learning 
Organization" say that like any other industry, insurance industry in India suffers from one challenge repeatable a hundred times, that is the constraints of infrastructure.

\section{Life Insurance}

Mehr and Cammack (1976) agrees that Insurance is usually thought of as a product that spreads the risk of serious, but low-probability, losses among a group of individuals, thus providing some financial protection to each individual.

\section{General Insurance}

Hammond et al. (1971), analyzed the extent to which economies of scale exist in the property and liability insurance industry. The sample for the study was comprised of 173 companies in all, which included 88 mutual insurers and 85 stock insurers in the year 1967.

\section{Customer Service}

Customer service is an organization's ability to supply their customers' wants and needs. Customer service is not only a decisive function, but also holds key position for the business. The superior customer services will unquestionably boost the profitability of business organizations. Services are the activities involved in accepting and safeguarding money owned by other individuals and entities, and then lending out this money in order to earn a profit. In the present study, customer services were considered as tangible and intangible offers made by the banks.

\section{Customer Satisfaction}

Satisfaction is an attitude or evaluation that is formed by the customer comparing their pre-purchase expectations of what they would receive from the product to their subjective perceptions of the performance they actually did receive. Several authors have defined satisfaction in a different way. Satisfaction is a person's feeling of pleasure or disappointment resulting from comparing a product's perceived performance (or outcome) in relation to his or her expectations. It is a function of consumer's belief that he or she was treated fairly. Satisfaction is determined by the discrepancy between perceived performance and cognitive standards, such as expectations and desires. Customers' expectation can be defined as customer's pretrial beliefs about a product.

Research Objective: To understand the role of Marital status and number of family members in customer service satisfaction

Research Proposition: The marital status and number of family members of the respondents differ in their level of customer service satisfaction.

\section{RESEARCH METHODOLOGY}

A dissatisfied customer will tell seven to 20 people about their negative experience. A satisfied customer will only tell three to five people about their positive experience (Kan 1995). The present study is descriptive in nature, and it describes customer's service satisfaction related to financial investment in General Insurance Corporation of India. The survey has been conducted in Tamil Nadu, which is one of the southern states of India. The study is based on multi-stage sampling method in state level districts. The simple random sampling method of statistical probability sampling using "lottery method" has been adhered to in the next stage, to identify the sample respondents. In Tamil Nadu, among the thirty 
two districts, researcher has selected five districts such as the southern district of Tirunelveli, south western district of Madurai, south eastern district of Trichy, eastern district of Cuddalore and northern district of Chennai. In order to establish the probability simple random sampling, the lottery method of lucky draw has been used. In total, 600 respondents were personally contacted to get a sample size of 550. To determine the sample size, the researcher used the formula of Schaeffer, Mendenhall and Ott (2005). The researcher applied relevant statistical tools for analyzing data describing VMP. The following are the relevant tools such as ANOVA, T-test and Chi-square test used for data analysis.

Table 1: Marital status and Customer Service Satisfaction

\begin{tabular}{|l|l|c|c|c|l|}
\hline \multicolumn{1}{|c|}{ Item } & Location & N & Mean & F & P- Value \\
\hline $\begin{array}{l}\text { Basic } \\
\text { Service } \\
\text { Satisfaction }\end{array}$ & Married & 324 & 23.8780 & \multirow{2}{*}{1.577} & 0.208 \\
\cline { 2 - 5 } & Unmarried & 226 & 22.7010 & & \\
\hline $\begin{array}{l}\text { Advanced } \\
\text { Service } \\
\text { Satisfaction }\end{array}$ & Married & 299 & 27.5061 & \multirow{2}{*}{2.449} & 0.002 \\
\cline { 2 - 4 } & Unmarried & 251 & 29.5155 & & \\
\hline
\end{tabular}

H1: The basic service satisfaction and advanced service satisfaction differ with the marital status of the respondents.

To test the significant difference among marital status and satisfaction, ' $t$ ' test have been used. The results are as follows. The obtained $\mathrm{p}$ value is significant with advanced service satisfaction as 0.002 , and it is lesser than the significant value 0.005 , and with the basic service satisfaction, the obtained $p$ value is 0.208 , which is higher than the significant value. Hence, it is found that there is a significant difference in advanced service satisfaction among the married and unmarried customers, and there is no difference among married and unmarried customers in their basic service satisfaction.

Table 2: Marital Status and Customer Service Satisfaction

\begin{tabular}{|l|c|c|c|c|}
\hline Marital Status & Basic Service & Advanced Service & Chi-Square Value & P-Value \\
\hline Married & 290 & 280 & \multirow{2}{*}{2.226} & \multirow{2}{*}{0.002} \\
\hline Unmarried & 260 & 270 & & \\
\hline Total & $\mathbf{5 5 0}$ & $\mathbf{5 5 0}$ & & \\
\hline
\end{tabular}

To find out the significant relationship in difference between customer service satisfaction and marital status, chisquare tests have been used. The result of chi-squared test is as follows. The chi-square value is 2.266 and the significant value is 0.002 , their obtained ' $\mathrm{P}$ ' value is lesser than 0.005 . Hence, the null hypothesis is accepted, so, there is significant relationship in difference among the married and unmarried respondents with their customer service satisfaction.

Table 3: Marital Status and Customer Service Satisfaction

\begin{tabular}{|c|c|c|c|c|c|}
\hline Dimension & Marital Status & Sum of Squares & Mean Square & $\mathbf{F}$ & P- Value \\
\hline \multirow{3}{*}{ Customer perception } & Between Groups & 22.954 & 5.739 & \multirow{3}{*}{.437} & \multirow{3}{*}{0.001} \\
\hline & Within Groups & 1178.611 & 5.926 & & \\
\hline & Total & 1901.565 & & & \\
\hline \multirow{3}{*}{ Customer motive } & Between Groups & 3.414 & 1.854 & \multirow{3}{*}{.284} & \multirow{3}{*}{0.002} \\
\hline & Within Groups & 1469.868 & 4.637 & & \\
\hline & Total & 1473.383 & & & \\
\hline \multirow{3}{*}{ Subjective factor } & Between Groups & 6.227 & 1.557 & \multirow{3}{*}{.333} & \multirow{3}{*}{0.001} \\
\hline & Within Groups & 1558.360 & 4.916 & & \\
\hline & Total & 1564.488 & & & \\
\hline \multirow{3}{*}{ Objective factor } & Between Groups & 25.261 & 6.315 & \multirow{3}{*}{.522} & \multirow{3}{*}{0.003} \\
\hline & Within Groups & 1315.000 & 4.48 & & \\
\hline & Total & 1340.261 & & & \\
\hline
\end{tabular}




\begin{tabular}{|c|c|c|c|c|c|}
\hline \multirow{3}{*}{ Basic Service Satisfaction } & Between Groups & 3.414 & 9.868 & \multirow{3}{*}{.468} & \multirow{3}{*}{0.004} \\
\hline & Within Groups & 1469.868 & 473.383 & & \\
\hline & Total & 473.383 & & & \\
\hline \multirow{3}{*}{$\begin{array}{l}\text { Advanced Service } \\
\text { Satisfaction }\end{array}$} & Between Groups & 6.227 & 558.0 & \multirow{3}{*}{.321} & \multirow{3}{*}{0.004} \\
\hline & Within Groups & 1558.360 & 144.488 & & \\
\hline & Total & 164.488 & & & \\
\hline
\end{tabular}

To test the significant difference between marital status and customer service satisfaction, one way Anova has been used, and the results obtained are as follows. The significant ' $\mathrm{P}$ ' value is 0.003 in basic service satisfaction and 002 is a value of advanced service satisfaction and it is lesser than 0.005 . Hence, the null hypothesis is accepted. It is clearly understood that there is significant difference between the marital status of respondents and their customer service satisfaction.

Table 4: Types of Family and Customer Service Satisfaction

\begin{tabular}{|c|c|c|c|c|c|}
\hline Factors & Family Members & $\mathbf{N}$ & Mean & $\mathbf{F}$ & P- Value \\
\hline \multirow{3}{*}{$\begin{array}{l}\text { Basic Service } \\
\text { Satisfaction }\end{array}$} & Nuclear & 184.3 & 23.8485 & \multirow{3}{*}{1.238} & \multirow{3}{*}{0.001} \\
\hline & Joint & 366.0 & 22.6075 & & \\
\hline & Total & 550 & 24.456 & & \\
\hline \multirow{3}{*}{$\begin{array}{l}\text { Advanced Service } \\
\text { Satisfaction }\end{array}$} & Nuclear & 278 & 29.4242 & \multirow{3}{*}{1.016} & \multirow{3}{*}{0.003} \\
\hline & Joint & 272 & 29.3364 & & \\
\hline & Total & 550 & 29.7606 & & \\
\hline
\end{tabular}

H1: The basic service satisfaction and advanced service satisfaction differ with family type.

To understand the significant difference among nuclear and joint families with customer service satisfaction, ' $t$ ' test was used. While considering basic service satisfaction, the results obtained were as follows. The nuclear family respondents scored high with their mean value at $23.8485(\mathrm{~N}=184)$, while joint family respondent scored 22.6075 $(\mathrm{N}=366)$, the ' $\mathrm{t}$ ' score is 1.238 and significant value of ' $\mathrm{P}$ ' is 0.001 , which is lesser than 0.005 . Hence, it is understood, there is significant difference among nuclear and joint family respondents with their basic service satisfaction. While looking into advance service satisfaction, their inferred results, the nuclear family respondents scored on high, with the mean value at 29.4242 ( $\mathrm{N}=278)$, while joint family respondents scored $29.3364(\mathrm{~N}=272)$. It is inferred that there is significant difference among nuclear and joint family respondents with their advanced service satisfaction.

Table 5: Type of Family and Customer Service Satisfaction

\begin{tabular}{|c|c|c|c|c|}
\hline Family & Basic Service & Advanced Service & Chi-Square Value & P-Value \\
\hline Nuclear & 310 & 355 & \multirow{2}{*}{2.456} & \multirow{2}{*}{0.000} \\
\hline Joint & 240 & 245 & & \\
\hline Total & $\mathbf{5 5 0}$ & $\mathbf{5 5 0}$ & & \\
\hline
\end{tabular}

To analyse the difference between customer service satisfaction and family, chi-square test have been done. The result of chi-square test is as follows. The chi-square test as followes, the chi-square value is 2.456 and the significant ' $\mathrm{P}$ ' value is 0.000 . The obtained ' $\mathrm{P}$ ' value is lesser than 0.05 . Hence, the null hypothesis is accepted, so there is significant difference among the nuclear and joint family respondent with their customer service satisfaction

Table 6: Type of Family and Customer Service Satisfaction

\begin{tabular}{|c|c|c|c|c|c|}
\hline Dimension & Type of Family & Sum of Squares & Mean Square & $\mathbf{F}$ & P- Value \\
\hline \multirow{3}{*}{ Customer perception } & Between Groups & 22.954 & 5.739 & \multirow{3}{*}{.888} & \multirow{3}{*}{0.001} \\
\hline & Within Groups & 1878.211 & 5.926 & & \\
\hline & Total & 0901.165 & & & \\
\hline
\end{tabular}




\begin{tabular}{|c|c|c|c|c|c|}
\hline \multirow{3}{*}{ Customer motive } & Between Groups & 3.414 & .854 & \multirow{3}{*}{.384} & \multirow{3}{*}{0.002} \\
\hline & Within Groups & 1469.868 & 4.637 & & \\
\hline & Total & 1473.383 & & & \\
\hline \multirow{3}{*}{ Subjective factor } & Between Groups & 6.227 & 1.557 & \multirow{3}{*}{.317} & \multirow{3}{*}{0.002} \\
\hline & Within Groups & 1558.360 & 4.916 & & \\
\hline & Total & 1564.488 & & & \\
\hline \multirow{3}{*}{ Objective factor } & Between Groups & 225.261 & 6.315 & \multirow{3}{*}{.622} & \multirow{3}{*}{0.003} \\
\hline & Within Groups & 1315.000 & 4.418 & & \\
\hline & Total & 340.261 & & & \\
\hline \multirow{3}{*}{ Basic Service Satisfaction } & Between Groups & 1879.422 & 1.462 & \multirow{3}{*}{.667} & \multirow{3}{*}{0.001} \\
\hline & Within Groups & 4412.189 & 1.478 & & \\
\hline & Total & 221.489 & & & \\
\hline \multirow{3}{*}{ Advanced Service Satisfaction } & Between Groups & 1481.258 & 11.698 & \multirow{3}{*}{.411} & \multirow{3}{*}{0.004} \\
\hline & Within Groups & 4222.574 & 1.548 & & \\
\hline & Total & 1.547 & & & \\
\hline
\end{tabular}

To test the significant difference between family members and customer service satisfaction, one way Anova has been used. The obtained 'P" value of advanced service satisfaction is 0.004 , and in basic service satisfaction, 0.001 is the value, and it is lesson than 0.005 .Hence, the null hypothesis is accepted, and it is clearly understood that there is significant difference between the type of family of and their customer service satisfaction.

\section{FINDINGS \& SUGGESTIONS}

There is a significant difference in advanced service satisfaction among the married and unmarried customers, and there is no difference among married and unmarried customers in their basic service satisfaction. There is significant difference among the nuclear and joint family respondents with their customer service satisfaction. The research finding is also supported by Bryant and Jaesung, 1996; Mittal et al., 2001, as Customer characteristics such as marital status and type of family have a great impact on the level of customer satisfaction.

\section{CONCLUSIONS}

The present study focused on the relationship between customer service satisfaction and the financial investor's marital status and family type at GIC. The findings indicate the significance of customer service in achieving customer satisfaction. It is right time to the health insurance companies to concentrate on this newer finding to help their customer more satisfied with their customer services. Hence, the companies can give more importance to new thrust areas to attain the untapped potential.

\section{REFERENCES}

1. Arora, S. (1988), "The GIC of India - An Appraisal", M.Phil. Thesis, Submitted to Department of Commerce, Delhi School of Economics, University of Delhi, Delhi.

2. Azam, M.S. (2005), "Customers' Attitude towards General Insurance Service: Contrasting the Public and Private Sectors in Bangladesh", Insurance Journal, July, pp. 91-109.

3. Banga, J.S. (2007), "Market Strategies of General Insurance Companies in India (A Study of Public Sector \& Private Sector)," Ph.D. Thesis, Submitted to Punjab School of Management Studies, Punjabi University, Patiala.

4. Diacon, S. (2001), "The Efficiency of U.K. General Insurance Companies", University of Nottingham, Centre for Risk and Insurance Studies, CRIS Discussion Paker Series-2001.111. www.nottingham.ac.uk/ business /ohic.com /index/ del/in.cris/papers/2001 -3.pdf dt.5-2-2007. 
5. Goswami, P. (2007), "Customer Satisfaction with Service Quality in the Life Insurance Industry in India", The ICFAI Journal of Services Marketing, Vol.V, No.1, pp. 25-29. 67.

6. Sinha, R.P. (2009), "Technical Efficiency of Indian General Insurance Companies: A Non-radial Approach", The ICFAI Journal of Risk and Insurance, Vol.VI, No. 1, pp. 16-29.

7. Verma, S. (2000), "Performance Appraisal of the General Insurance Corporation of India", M.Phil. Thesis, Submitted to Department of Commerce, Delhi School of Economics, University of Delhi, Delhi. 
